\title{
Targeting of peripheral blood T Lymphocytes
}

\author{
Reinder L.H. Bolhuis ${ }^{1}$, Hennie R. Hoogenboom ${ }^{2}$, Jan Willem Gratama ${ }^{1}$ \\ ${ }^{1}$ Department of Clinical and Tumor Immunology, Daniel den Hoed Cancer Center; \\ ${ }^{2}$ CESAME at Department Pathology, University Hospital Maastricht, The Netherlands
}

\section{Introduction}

New prospects for an immunologically based strategy of the treatment of cancer and infectious diseases are regularly highlighted in the preclinical and clinical literature. The hallmark of the immunologically based therapeutic strategies is the specificity for the cancer or virally infected tissues by virtue of the presence of specific receptors on populations of immune cells, e.g., T lymphocytes. Hence immune attack leaves normal or non-infected tissues intact. This idea goes back to the beginning of the twentieth century; in Germany, Paul Ehrlich put forward his hypothesis of "magic bullets" [30] and Von Leyden and Blumenthal initiated their studies aimed at active immunization of cancer patients against their own cancerous tissue. During the subsequent 6 decades, cancer patients were non-specifically immunostimulated using relatively crude leukocyte extracts such as transfer factor, immune RNA, or from bacterial extracts, e.g., bacillus Calmette-Guérin (BCG), levamisole, and Coley's toxin. In those days very little was known about the various components of the immune system that could react against cancer, and even less was known about tumor-associated antigens.

In the 1960s Burnett formulated the immuno-surveillance theory, highlighting that cell-mediated immunity played a critical role in the control of cancer and infectious diseases [18]. In order to discriminate between malignant cells or infected cells and normal tissues it was postulated that $\mathrm{T}$ cells during ontogeny learned to distinguish "self" (which should be left intact) from "non-self" (which should be eliminated). Hence, one of the major tasks of the host immune $\mathrm{T}$ cells was to continuously monitor whether in the host "self" became "altered self" due to, e.g., viral infection of cells or neoplastic transformation.

Recently, Ridge et al. [84] have proposed that discrimination between "self/nonself" is a life-long during process in which foreign molecules are also tolerant to the 
T cells, if the co-stimulatory signal (second signal) is not accompanied by a "danger" signal. Tumors, when they arise, do not represent imminent danger to their host, and hence the immune system may become tolerant to the tumor-associated antigen or, in other words, anergic. By the time tumors are life threatening, the tolerant immune system ignores the tumor, unless immune activation occurs by artificially targeting $\mathrm{T}$ cells to the tumor cells with the ultimate aim of breaking tolerance and possibly inducing systemic immunity with immunological memory. The important task of the immune system therefore is to guarantee the integrity of the internal environment of the host by detecting and eliminating potentially harmful, undesired alterations or infiltrations: immune surveillance.

Research during the past 30 years has led to the identification and characterization of a number of immune effector cells, such as natural killer (NK) cells, macrophages, and immune $T$ and $B$ cells, the latter producing antibodies following their maturation into plasma cells. The effector mechanisms range from cytolysis, which is the process of target cell destruction, to cytostasis, the latter being the growth arrest of target cells. The advent of new biotechnologies, such as the production of monoclonal antibodies (mAbs), in vitro expansion of immune $\mathrm{T}$ cells, gene cloning, and viral vector-mediated gene transfer to recipient cells, has allowed the identification of the individual molecules on immune effector cells and their target cells involved in immune reactions. The concerted, scaled-up use of these technologies allows us to specifically target genes of choice to either immune cells or target cells, aiming to repair genetic defects in cells and to cause their destruction or to redirect specificity of immune cells.

In this review we will first describe the $T$ cell and target cell structures that are well known to play major roles in effector lymphocyte/target cell interactions and subsequently will focus our attention on the following targeting strategies: (1) production of bispecific $\mathrm{mAbs}$ (bs-mAbs) and single chain $\mathrm{Fv}(\mathrm{scFv})-\mathrm{mAb}$ for targeting of T cells; (2) targeting of $\mathrm{T}$ cells with bs-mAb; (3) targeting of $\mathrm{T}$ cells by genetically engineering single chain $\mathrm{Ig} / \gamma$ or $\zeta$ receptors into $\mathrm{T}$ cells.

\section{Cytotoxic T lymphocyte/target cell interactions}

The physical interaction between effector cells, i.e., cytotoxic T lymphocytes (CTL) and target cells involves the establishment of multiple bonds between effector and target cells mediated by $\mathrm{T}$ cell receptors (TCRs) and adhesion molecules, which are both present on all CTLs.

\section{TCRs and immunoglobulins}

Antigen-specific T cells and CTL express TCRs on their membrane which specifically bind target cell antigen (Ag). Most $\mathrm{T}$ cells, including $\mathrm{CTL}$, recognize and bind to "non-self" Ag. These Ags are bound to and presented by major histocompatibility complex (MHC) class I or II molecules on the surface of Ag-presenting cells (e.g., dendritic cells) or target cells by the effector cells. The TCR initiates the recognition and binding of target cells. The TCR is a multi-component complex consisting of an immunoglobulin (Ig)-like Ag binding portion, the polymorphic $\alpha \beta$ or $\gamma \delta$ TCR, which is non-covalently linked to the non-polymorphic signal-transducing proteins, $\mathrm{CD} 3 / \delta \epsilon$, 
$\mathrm{CD} 3 / \gamma \epsilon, \zeta$ and $\eta$. TCR recognize $\mathrm{Ag}$ in the context of MHC on the target cells, whilst $\mathrm{Ab}$ molecules, i.e., Igs, recognize soluble Ag. In the B cell receptor complex, CD79 functions as the analogue of CD3 for TCR. Nevertheless TCR and Ig share many structural characteristics, e.g., both molecules are disulfate-linked heterodimers or tetradimers, TCR and Ig genes are assembled in an identical way, and both contain an invariant constant (C) region and an Ag-binding variable (V) region [21, 25]. The Ag diversity of the TCR and Ig, the hallmark of the immune system, is created by similar processes of genetic rearrangements involving the variable (V), diversity (D, and for Ig heavy chain, H), and joining (J) gene segments. Only in the case of Ig do somatic mutations add to Ag diversity. In short the V,D, and $\mathrm{J}$ segments are combined to form the Ag-binding domains. For Ig-mediated effector functions, the Ig $\mathrm{C}$ region interacts with complement and $\mathrm{Fc}$ receptors on monocytes, NK cells, and some $\mathrm{T}$ cells. In contrast, the $\mathrm{C}$ region of the TCR contains a transmembrane structure anchored to the $\mathrm{T}$ cell surface, which takes part in the signalling process via the $\mathrm{CD} 3$ complex following $\mathrm{Ag}$ recognition by the TCR. The fashion and form in which proteins fold are critical for their biological function, and for Ig and TCR, both members of the Ig supergene family, the foldings are similar.

\section{Adhesion and co-activation molecules on $T$ cells}

TCR and CD28 each have counter-regulatory molecules which are expressed on the T cell membrane, for TCR the NK receptor gene family [81] and for CD28 the CTLA$4[55,69,92]$. These counter-regulatory molecules, which only become expressed on activated $\mathrm{T}$ cells, deliver a negative signal to $\mathrm{T}$ cells, and the immune response returns to the baseline state: self-limiting immune response. TCRs which recognize antigens without a co-stimulatory signal will become anergic or tolerant. The bestcharacterized second signalling molecule thus far is $\operatorname{CD} 28[69,92]$. The intrinsic binding affinities of TCRs for $\mathrm{Ag}$ are low to moderate in comparison to $\mathrm{Ab}$, and the number of MHC peptides per target cell that form complexes with the TCR is also low [109]. Nevertheless, even the low numbers of TCR/Ag complexes formed following Ag recognition by the TCR induce a rapid increase in affinity of the adhesion molecules, e.g., lymphocyte function-associated antigen-1 (LFA-1) for its target cell ligand intercellular adhesion molecule-1 (ICAM-1). The increase in affinity does not require an increase in LFA-1 cell surface density on the T cells [11]. CD2 on T cells and ICAM-3 on the target cells are also involved in the adhesion processes $[14,38]$. Consequently, where no foreign $\mathrm{Ag}$ is expressed on normal cells, turning dangerous "self" into "non-self", T cells with dangerous "non-self" recognizing TCRs will not bind to any "self" and continue their immunosurveillance.

A second group of accessory molecules are the very late Ag (VLA), a subfamily of integrins (VLA 3, 4, 5, and 6]. These molecules recognize collagen, fibronectin, and laminin, which are present in the extracellular matrix of target cells $[102,114]$. Thirdly, CD44, which also recognizes extracellular matrix proteins such as glycosaminoglycans (e.g., hyaluronate and chondroitin sulfate), does not belong to the integrin family $[24,67]$. The extracellular matrix proteins are critical in guiding the trafficking of immune cells to particular organs and most likely influence the maturation process of $T$ cells as they interact with the receptors on the $T$ cells [114].

Several of the adhesion molecules, such as CD2, can also serve as signaltransducing receptors themselves, provided they become crosslinked [10, 37]. Com- 
binations of mAbs against distinct signalling molecules (e.g., $\mathrm{CD} 2$ and $\mathrm{CD} 3$ or $\mathrm{CD} 16$ etc.) critically enhance the $T$ lymphocyte activation process $[9,13,110,111]$. Other molecules that can serve as signal-transducing receptors are CD44 [34, 97], present on interleukin-2-activated NK cells but also on a small amount of $\mathrm{CD}^{+} 6^{+} \mathrm{T}$ cells [93], and CD69, an early activation marker on $T$ cells which serves as a cytotoxic triggering molecule on NK clones and $\gamma \delta$ T lymphocyte clones [76]. The CD8 and CD4 molecules on T cells which specifically associate with the same MHC class I or II molecule that present Ag also secure stabilization of the $\mathrm{T}$ cell/target cell interaction and enhance the signalling process.

In summary, crosslinking of multiple TCRs on individual effector cells with multiple Ags on the individual target cells, the occurrence of additional bonds between CD4 or CD8 cytotoxic T cells and MHC/Ag, and crosslinking between T lymphocyte adhesion molecules and target cell ligands, which all move towards the contact region between $\mathrm{T}$ cells and target cells, result in conjugate formation between $\mathrm{T}$ cells and target cells, stabilization of the cell conjugates, increase in overall TCR/Ag affinity, signal transduction through the $\operatorname{CD} 3 / \epsilon \delta[15,23,26]$ and $\epsilon$ portions $[8,62,66,80$, $90,91,98]$ (patch formation in the contact region), lymphokine production by $\mathrm{T}$ helper/inducer cells and CTL, and cytolysis of target cells by CTLs.

\section{The CTL lytic mechanisms}

CTL-induced target cell lysis is an apoptotic process. During CTL/target cell interaction aggregation of TCR, co-stimulatory molecules, and adhesion molecules takes place. The CTL microtubule organizing center arrives at the CTL-target cell contact region followed by an accumulation of cytoskeleton elements at the interaction site $[36,61]$. The result is selective exocytosis of specialized cytolysins into the narrow gap between the interacting cells [45].

Perforins. The exocytosed granules contain perforin and a plethora of other enzymes including granzymes [108]. Perforin shows homology with complement proteins, in particular the pore-forming protein $\mathrm{C} 9$, and produces the lysis-inducing pores in the target cells $[29,51,68,99]$ (in the presence of calcium perforins form aggregates resulting in cylindrical structures that are inserted into the lipid bilayer of the target cell membrane). The result is apoptosis: the target cell chromatin condenses, its membrane blebs, its DNA breaks up into oligonucleosome-length DNA fragments, consequently the cells shrink, its endoplasmic reticulum dilates, and finally the target cells become fragmented: sealed membrane fragments (apoptotic bodies) are produced [4]. The susceptibility of the target cell to this apoptotic death is dependent on the stage of the mitotic cycle of the target cell: quiescent (G0) cells are refractory whereas G1 stage target cells are susceptible to CTL-induced DNA fragmentation [78, 89]. Consequently the physical association and aggregation at the contact region between CTL and target cells does not only stabilize the conjugate formation between the effector and target cells following initial TCR recognition, but also channels the exocytosed perforins and granzymes, thereby avoiding death of innocent healthy "bystander" cells which are adjacent to the aberrant target cells. The chance of innocent bystander target cell lysis is further decreased because of the short half life of cytolysins in serum.

In summary, the lytic protein perforin is a critical cytolysin in this cytocidal mechanism. Besides these natural serine proteases (perforins, granzymes), both of which are stored in unique secretory CTL granules $[45,82,100]$, calcium is involved 
in the degranulation process of the effector cell $[29,51]$. The DNA breakdown, however, is caused by the granule proteases $[45,101]$.

Fas-Fas-ligand interactions. Recently it has been shown that CTL devoid of perforin could nevertheless lyze their target cells. These CTL showed a specific alloreactive CTL response in mixed lymphocyte cultures and protected mice in vivo against intraperitoneally administered tumor allografts $[56,57,70,116]$. This mechanism is now known to involve Fas and Fas ligand (FasL), two cell surface proteins that are homologous to tumor necrosis factor (TNF) and TNF $\alpha$ receptor, respectively [52, 72]. When the FasL on the target cells is crosslinked by Fas on the effector T cells [72] or by Abs [107], the target cell is triggered into an apoptotic suicide mechanism.

In summary, potent and specific CTL-mediated lysis of target cells occurs by at least two distinct mechanisms: (1) the secretion of cytolysins and the perforinmediated pathway cause direct pore-forming channels in target cells through which the lysis-inducing enzymes can enter the target cells, resulting in granule protease-induced DNA fragmentation, the process of target cell apoptosis; (2) the CTL Fas/target cell FasL-dependent pathway involves the triggering of a programmed disintegration of the CTL-bound target cell.

\section{Anti-TCR mAb mimic TCR/Ag interactions}

For $\mathrm{T}$ cell activation, $\mathrm{Ag}$ can be substituted by mAbs, provided they are specific for and hence bind to: the Ag-binding part of the polymorphic TCR $\alpha \beta$ (e.g., anti-TCR idiotypic Abs) or any of the non-polymorphic signalling structures of the TCR/CD3 complex, because otherwise only cell/cell conjugate formation will occur upon interaction with irrelevant target cells. Following crosslinking of the TCR complexes by these mAbs, $T$ cells then become activated as if the TCRs were interacting with their natural target cell ligands, as described earlier [15, 23, 26]. Again, all these cell surface molecules co-aggregate in the contact region between $\mathrm{T}$ cell and target cell as if normal TCR/Ag interactions were taking place. This also explains why triggering through any of these signalling molecules have the same result: $T$ lymphocyte activation and/or triggering of $\mathrm{T}$ cell-mediated target cell lysis.

\section{Targeting of CTL by bs-mAbs or chimeric Ig-receptor genes}

Cellular based therapies utilizing tumor-reactive $T$ cells have been developed for patients with metastatic melanoma, resulting in significant tumor reduction in some patients $[87,88]$. However, the generation or isolation of tumor-specific CTLs has proved extremely difficult, laborious, and time consuming, and hence has, as yet, not been exploited for immunotherapy. In contrast, a plethora of mAbs have been generated that recognize tumor-associated antigens common to certain cancers. To combine the ability of mAbs to selectively recognize tumor-associated antigens with the potent anti-tumor effector functions of $\mathrm{T}$ cells, and specifically CTLs, we and others designed bs-mAbs and chimeric Ig-receptor genes to retarget the specificity of $\mathrm{T}$ cells for tumor-associated antigens. 


\section{Production of bs-mAb and single chain Fv (scFv) Ab}

The bs-mAbs can be produced by chemically coupling two types of mAbs with defined specificities [44]. This method is inefficient and unreliable because it yields unstable material. The hybrid-hybridoma technology has already proved to be a more sophisticated and reliable method [112], although this method also produces bs-mAbs with undesirable chain combinations, requiring the isolation of the relevant bs-mAbs.

The central concept of the bs-mAb approach for the retargeting of $T$ lymphocyte specificity is that the bs-mAb with specificities for a particular tumor-associated antigen on target cells and for effector $T$ cells crosslink the effector and target cells thereby triggering immune attack [112]. The availability of large-scale culture technologies for the production of human activated $T$ cells combined with an array of $\mathrm{mAbs}$ specific for $\mathrm{T}$ lymphocyte activation molecules has allowed the application of the general concept of redirection of $T$ lymphocyte specificity by means of adoptive transfer of bs-mAb redirected $T$ cells to clinical treatment of cancer. It has now been clearly demonstrated that bs-mAbs specifically redirect CTLs of all specificities towards human and animal cancer cells inducing tumor cell lysis [94-96].

With the recent advances in antibody gene engineering [121], bispecific molecules can be made even more easily by the production of molecularly engineered versions, including scFv fragments provided with multimerization domains or tags, $\mathrm{scFv} 2 \mathrm{~s}$, or dimerized and crosspaired scFv's, so called diabodies [46, 47, 58, 79]. In particular, the relative ease of producing diabodies [123], combined with their demonstrated efficacy in retargeting $T$ cells to tumor cells [123], suggests that this format will provide a significant stimulus to the further development of therapeutic bispecific molecules. A second advantage of the molecular route is the speed with which many different bispecific molecules can be made and screened, allowing the tailoring of both affinity and specificity of the antibodies.

Immune responses to the bispecific antibody or the retargeted $\mathrm{T}$ cell can be reduced dramatically and sometimes avoided entirely by using genes encoding antibody fragments of human origin. These types of Abs are now readily available, mainly due to the advances made with the phage display technique. Phage display involves the expression of proteins on the surface of phage as fusion proteins attached to normal phage coat proteins. The physical link between the protein on the surface of the phage and the gene which encodes it within the phage allows a rapid evolution of protein properties on the basis of binding, by a series of repetitive cycles of phage binding, elution, and regrowth to amplify the selected phage population. One of the most successful applications of phage display has been the derivation of $\mathrm{mAbs}$ using large phage antibody libraries, and the subsequent improvement of the affinity of selected antibodies by their mutation and further selection [122]. Antigen-specific antibodies are selected from libraries of randomly paired combinations of variable domains of heavy and light chains (formatted as scFv [74], Fab [48], or diabody fragments), which are displayed on the surface of filamentous bacteriophage via fusion to the minor coat protein pIII. To generate human antibodies, the libraries are made from "naive" B cells from human donors [73], or from cloned human V gene segments [49]. A number of very large collections of human antibodies have been made, with over 10 billion different antibodies, allowing the isolation of antibodies to any chosen antigen and with a moderate to high affinity $(10 \mathrm{nM}-0.3 \mathrm{nM})[40,115]$. Human Fab or $\mathrm{scFv}$ fragments with tumor antigen binding characteristics can thus be isolated from 
such libraries and their genes directly transfected into CTLs for retargeting to tumor cells.

\section{bs-mAb-mediated $T$ cell targeting: redirection of CTL specificity}

We and others have exploited the phenomenon that mAbs, by crosslinking the relevant antigens, induce lymphocyte activation and trigger the lytic machinery of $\mathrm{T}$ cells by generation and use of bs-mAbs [112]. bs-mAbs recognize a $\mathrm{T}$ cell triggering molecule, e.g., $\mathrm{CD} 3 \zeta$, and a tumor-associated antigen cell surface molecule. Crosslinking of the signalling/adhesion molecules occurs when bs-mAb crosslink them to the tumor-associated antigens on tumor cells by virtue of their dual specificity: bs-mAb recognize, e.g. $\mathrm{CD} 3-\zeta$ on T cells on the one hand and tumor-associated antigens on the target cells on the other. The same $\mathrm{CD} 3-\zeta$ is expressed on all $\mathrm{T}$ cells, irrespective of their antigen specificity, all $\mathrm{T}$ cells become activated and all activated CTL are triggered to lyze the tumor-associated antigen-expressing target cell.

\section{Lymphokine production by bs-mAb-retargeted $T$ cells}

From in vivo studies aimed at tumor neutralization in nude mice it appeared that much lower numbers of effector cells were required to inhibit tumor growth in vivo than required to induce lysis in vitro [106], and that supernatants obtained from peripheral blood lymphocytes inhibited growth of tumor cells which themselves were not recognized by the Ab-targeted T cells. Hence, the inhibition of "bystander" tumor cell growth did not require effector cell/target cell contact. That lymphokine production induced by lymphocyte triggering molecules was indeed responsible for the inhibition of tumor growth was demonstrated by the addition of cytokine-specific $\mathrm{mAbs}$, particularly anti-TNF $\alpha$ and anti-interferon- $\gamma \mathrm{mAbs}$, which abrogated the tumor growth inhibitory activity [28]. A number of other lymphokines are also triggered by crosslinking of activation molecules, in particular inflammatory lymphokines that can recruit and act on other cellular components of the immune system and induce homing of immune cells to target cells.

This site-specific induction of the immune reactions has great advantage over the systemic administration of cytokines such as interferon- $\alpha$, TNF- $\alpha$ or interleukin2 , and others, because these highly active biomolecules have pleiotropic effects on many different cell types, and hence may cause unwanted toxic effects in the patient. Moreover, generally these lymphokines have a short half-life, function at a short range, and interact with specific cell surface receptors. These interactions trigger the delivery of signals to target cells which affect their gene expression, proliferation and differentiation, and ultimately cause their death (apoptosis); the effect(s) occur depending on their degree of differentiation and maturation. Site-specific immune reactivity avoids systemic toxic effects of cytokines by virtue of specific trafficking and homing of immune $\mathrm{T}$ cells to the target site by retargeting $\mathrm{T}$ cell specificity with bs-mAb or scFv chimeric receptors.

In summary, redirection of $T$ cell specificity results in cytokine-triggered inflammatory reactions at the target site, mobilizing the different effector arms of the immune system. The immune activation may result in systemic, specific humoral and cellular immune responses against the tumor and tumor regression by CTLs. 


\section{Immunotherapy}

\section{Animal models}

Now that in vitro studies have proved that bs-mAbs efficiently redirect $\mathrm{T}$ lymphocyte specificity towards tumor cells (or virus-infected cells) and subsequently trigger cytokine production and cytolysis of the target cells, suitable animal models have been developed to study their in vivo functions. Two models have been developed (1) a xenograft model in which human tumors were transplanted into immunodeficient nude mice, followed by treatment of the tumor xenograft by bs-mAb-targeted human $\mathrm{T}$ cells; (2) a syngeneic model in which murine bs-mAbs, tumors, and $\mathrm{T}$ cells are used.

Early studies involved the treatment of syngeneic lymphoma with activated hostderived T cells and bs-mAbs directed against V $\beta 8$ TCR and Thy 1.1. on the lymphoma cells, and showed tumor protection $[15,16,26-28,117-119]$. bs-mAb-mediated therapy was also successful in syngeneic solid tumor animal models [5, 118]. In the xenograft studies CTLs, bs-mAbs, and tumor cells were mixed and injected subcutaneously into nude mice: a Winn-type assay [106]. The anti-cancer effect involved direct lyzing of the tumor cells [106], as well as tumor growth inhibition by cytokines released by these activated $\mathrm{T}$ cells [83]. Even established ovarian carcinoma xenografts growing intraperitoneally in nude mice could be successfully treated with bs-mAbs (OCTR) targeted to CD3 on the T cells on the one hand and to a human folate binding protein (MOV-18), which is overexpressed in ovarian carcinoma cells on the other hand $[19,35]$. Also, human $\mathrm{T}$ cells prolonged survival in this model system [75, 113]. Subsequently, syngeneic models [1,3] were developed to avoid irrelevant activation conditions obviously occurring in a xenogeneic system due to incompatibilities between donor and host adhesion molecules and their ligands. Such incompatibilities can result in abnormal trafficking of the human $\mathrm{T}$ cells in animals. These studies served as preclinical models for the design of patient treatment protocols.

\section{Clinical studies}

The first international multicenter study involved locoregional treatment of ovarian carcinoma cells in patients with advanced disease $[12,20]$. The high frequency of relapse of advanced ovarian carcinoma after induction chemotherapy called for a new therapeutic strategy. Prior to entry into the study, laparotomy was performed to reduce tumor load and to indicate remaining macroscopical lesions. We treated 28 patients with two 5-day cycles of treatment, consisting of daily intraperitoneal injections of autologous activated $T$ cells, which had been expanded in vitro following activation with phytohemagglutinin and addition of exogenous interleukin-2 for each of the ten infusions and retargeted with the bs-mAb OC/TR specific for $\mathrm{CD} 3$ and for the folate receptor overexpressed by ovarian carcinoma cells. T cells $\left[10^{9}\right]$ were incubated with $1 \mathrm{mg}$ bs-mAb. The patients received additional infusions of interleukin- 2 and bs-mAb after each administration of targeted $T$ cells to maintain the lytic activity of the retargeted T lymphocytes; 6-10 weeks following treatment those patients without signs of tumor progression underwent explorative laparotomy for objective assessment of tumor response by comparing remaining tumor with that documented by pretreatment 
laparotomy. The overall intraperitoneal response rate was $27 \%$. Complete responses were seen in 3 patients, and lasted 26 months, 23 months, and 18 months, respectively. Toxicity of the treatment was mild, WHO grade II.

Of 24 patients evaluated, 23 developed a human anti-mouse antibody (HAMA) response [20]. In vitro studies showed that although during treatment cycles the levels of HAMA increased with time, HAMA did not block the bs-mAb-mediated triggering of cytolysis and cytokine production by the patient's $\mathrm{T}$ cells until day 40 following the first administration of bs-mAb, i.e., after the 2 cycles of treatment were completed [64]. Other pilot studies that followed reported the treatment of patients with malignant ascites or pleural effusions resulting from colon, mammary, ovarian, lung, and gastric carcinomas. These patients were treated locally with ex vivo activated autologous cells and an anti-CD3-based bs-mAb. Again, the bs-mAb-targeted $\mathrm{T}$ cells exerted strong local biological effects within hours: conjugates between tumor cells and $\mathrm{T}$ cells were identified with a decrease in tumor cell number and in serum levels of carcino-embryonic antigen. Elevated levels of cytokines and an increase in granulocyte numbers were also observed [59].

The anti-cancer effects obtained so far with bs-mAb-retargeted $\mathrm{T}$ lymphocytes have been locoregional. Systemic administration of bs-mAb-retargeted activated $T$ cells is expected to be more effective for systemic anti-cancer effects, as demonstrated by mouse studies. There is only limited experience of systemic treatment with bs-mAb. One ovarian cancer patient treated with intravenous infusion of $1 \mathrm{mg}$ of the bs-mAb used for the locoregional treatment suffered severe toxicity starting $30 \mathrm{~min}$ after administration [105], and other patients showed similar toxicity (Bolis, Milan; personal communication). The patients developed chills, headache, fever in combination with hypertension, and fatigue, although all symptoms resolved after treatment was discontinued. The toxicity was most likely due to an increase in serum TNF $\alpha$ levels. Other studies revealed extravasation of $\mathrm{T}$ cells following intravenous injection of bs-mAb and a subsequent rise in TNF- $\alpha[54,60]$, probably due to crosslinking of the bs-mAb-targeted TCR, following binding to tumor cell antigens or crossreactive normal tissue.

In conclusion, the clinical studies involving bs-mAb-targeted $\mathrm{T}$ cells have shown "proof of principle," and have yielded encouraging results, even in the locoregional therapy of advanced stages of disease with tumors already resistant to standard treatment regimens [20]. Therefore this approach deserves further testing, focusing on how toxicity following systemic administration can be avoided. The most appropriate setting for this bs-mAb-targeted $\mathrm{T}$ lymphocyte approach is ultimately expected to be the treatment of minimal residual disease following standard therapy. In such an adjuvant setting the bs-mAb-targeted $\mathrm{T}$ cells are expected to effectively attack and destroy circulating tumor cells and small metastases.

\section{Immuno-gene-therapy}

Retargeting of T lymphocyte specificity with chimeric receptor genes encoding Abtype specificity

The use of bs-mAb for therapy may be hampered by the inaccessibility of solid tumors to antibody penetration [53]. Moreover, bs-mAb-redirected CTL retain the bispecific antibody for only limited periods (i.e., 48-96h) due to dissociation from the CTL 
surface [7, 65]. In addition, bs-mAb-redirected CTL lose signal transduction and lytic capacity following target cell recognition, lysis, and TCR/CD3 complex clustering [7].

Because systemic eradication of tumors requires long-lasting, systemic immune responses, molecular engineering of chimeric receptors with $A b$-dictated specificity into $\mathrm{T}$ cells or other immune cells may result in such a sustained immune response. Because each immune cell population shows specific patterns of cytokine production, e.g., $\mathrm{T}$ helper 1 versus $\mathrm{T}$ helper 2 cells, NK cells, antigen-presenting dendritic cells, etc., each population can trigger different immunological responses and therapeutic outcomes [86, 104]. The future gene retargeting of the specificity of these individual populations will allow further fine-tuning of immuno-gene-therapy strategies.

To this end we and others have adopted an approach in which $\mathrm{T}$ cells are "gene grafted" with a permanent antibody-dictated specificity $[31,103]$. This molecular approach to graft $T$ cells with a predetermined antibody specificity exploits the already described structural similarity between $\mathrm{Ab}$ and TCR molecules. It is possible to construct chimeric genes in which the Ab recognition unit has been used in the form of a single-chain $\mathrm{Fv}$ (scFv)-encoding gene, to create hybrid molecules in which the signalling subunits are molecules such as the $\zeta$-chain derived from the CD3 complex or the $\gamma$-chain from the high-affinity receptor for $\operatorname{IgE~Fc} \epsilon-\mathrm{RI}$. In another approach the TCR variable region is replaced by an Ab variable region in a chimeric TCR gene. The variable domains of $\mathrm{mAb}$ fused by a flexible linker sequence have been shown to display similar binding affinities and specificities compared with those of the natural $\mathrm{mAb}[6,22,120]$.

To transfect genes to primary $\mathrm{T}$ cells, retroviral vectors have been adapted for the delivery of foreign genes to primary human cells $[2,16,32,33,39,41-43,63,71,85]$. Chimeric receptors are then cloned into these retroviral vectors, which transduce the chimeric genes into, e.g., $T$ cells where they become stably integrated in the cellular DNA. The integration of the chimeric receptor encoding gene in the cellular DNA results in synthesis of the chimeric proteins and expression on the lymphocyte surface. The original studies used the two-chain receptor approach, with $V_{H}$ and $V_{L}$ linked to the $\alpha$ and $\beta$ chains of the TCR $[2,41,42,63]$, followed by the single chain receptor (scFv) approaches, which allowed the expression of full $\mathrm{Ab}$ specificity on a single receptor molecule. Various anti-tumor $\mathrm{mAbs}$ have been engineered into a single-chain format and expressed on the surface of the CTL [50]. Single-chain antibodies (scFv) juxtaposed to a signal-transducing molecule, like the $\operatorname{Fc}(\epsilon) \operatorname{RI} \gamma$ or TCR $\zeta$ chain, have now been functionally expressed in mouse $\mathrm{T}$ cell hybridomas or CTL $[17,31,77$, $103]$, tumor-infiltrating lymphocytes, and human $\mathrm{CD}^{+} \mathrm{T}$ cells $[50,85]$.

\section{Conclusions}

In summary, human single-chain gene transduced $T$ cells were shown: to express the $\mathrm{scFv}$ on their surface, to recognize their relevant ligand (tumor-associated antigen) on tumor target cells, to produce cytokines and, to lyze tumor cells. In our earlier review on retargeting $T$ lymphocyte specificity [11], we concluded that a number of questions needed to be answered: (1) Is triggering of cytolysis by CTL or lymphokine production most important to generate anti-cancer effects? Both are important, especially to eliminate bystander cells which do not express tumor-associated antigen [35, $75,83,106]$. (2) Can targeted CTL traffick and home to the tumor site? Yes, they can. 
(3) Does "humanization" of mouse mAbs reduce HAMA responses? Our preliminary experiences suggest that this is the case (unpublished data).

Significant progress has therefore been made in the laboratory and in clinical tests, and will continue to be made. We are now preparing for the clinical phase $1 / I I$ testing of in vivo anti-tumor activity of $\mathrm{T}$ lymphocytes retargeted by transfer of chimeric receptor genes encoding Ab-type specificity.

\section{References}

1. Bakács T, Lee J, Belen Moreno M, Zacharchuk CM, Cole MS, Yun Tso J, Paik CH, Ward JM, Segal DM (1995) A bispecific antibody prolongs survival in mice bearing lung metastases of syngeneic mammary adenocarcinoma. Int Immunol 6:947

2. Becker MLB, Near R, Mudgett-Hunter M, Margolies MN, Kubo RT, Kaye J, Hedrick SM (1989) Expression of hybrid immunoglobulin - $\mathrm{T}$ cell receptor protein in transgenic mice. Cell 58:911

3. Belen Moreno M, Titus JA, Cole MS, Yun Tso J, Nhat Le, Paik CH, Bakäcs T, Zacharchuk CM, Segal DM, Wunderlich JR (1995) Bispecific antibodies retarget murine $\mathrm{T}$ cell cytotoxicity against syngeneic breast cancer in vitro and in vivo. Cancer Immunol Immunother 40:182

4. Berke G (1995) The CTLs kiss of death. Cell 81:9

5. Beun GD, Eendenburg DH van, Corver WE, Van de Velde CJH, Fleuren GJ (1992) T-cell retargeting using bispecific monoclonal antibodies in a rat colon carcinoma model. I. Significant bispecific lysis of syngeneic colon carcinoma CC531 is critically dependent on prolonged preactivation of effector T-lymphocytes by immobilized anti-T-cell receptor antibody. J Immunother 11:238

6. Bird RE, Hardman KD, Jacobson JW, Johnson S, Kaufman BM, Lee SM, Lee T, Pope SH, Riordan GS, Whitlow M (1988) Single chain antigen binding proteins. Science 242:423

7. Blank-Voorthuis CJAC, Braakman E, Ronteltap CPM, Tilly BC, Sturm E, Warnaar SO, Bolhuis RLH (1993) Clustered CD3/TCR complexes do not transduce activation signals after bispecific monoclonal antibody-triggered lysis by CTL via CD3. J Immunol 151:2904

8. Blue ML, Hafler DA, Craig KA, Levine H, Schlossman SF (1987) Phosphorylation of CD4 and CD8 molecules following $\mathrm{T}$ cell triggering. J Immunol 139:3949

9. Bolhuis RLH, Roozemond RC, Van de Griend RJ (1986) Induction and blocking of cytolysis in $\mathrm{CD} 2{ }^{+} \mathrm{CD}^{+} \mathrm{NK}$ and $\mathrm{CD} 2{ }^{+}, \mathrm{CD}^{+}$cytotoxic $\mathrm{T}$ lymphocytes via $\mathrm{CD} 250 \mathrm{KD}$ sheep erythrocyte receptor. J Immunol 136:3939

10. Bolhuis RLH, Gravekamp C, Van de Griend RJ (1986) Cell-cell interactions. Clin Immunol Allergy $6: 29$

11. Bolhuis RLH, Sturm E, Braakman E (1991) T-cell targeting in cancer therapy. Cancer Immunol Immunother 34:1

12. Bolhuis RLH, Lamers CHJ, Goey SH, Eggermont AMM, Trimbos JBMZ, Stoter G, Lanzavecchia A, Di Re E, Miotti S, Raspagliesi F, Rivoltini L, Colnaghi MI (1992) Adoptive immunotherapy of ovarian carcinoma with bs-mAb-targeted lymphocytes: a multicenter study. Int J Cancer 7:78

13. Borst J, Van de Griend RJ, Van Oostveen JW, Ang S-L, Melief CJ, Seidman JG, Bolhuis RLH (1987) A T-cell receptor $\gamma / \mathrm{CD} 3$ complex found on cloned functional lymphocytes. Nature 325:683

14. Braakman E, Goedegebuure PS, Vreugdenhil RJ, Segal DM, Shaw S, Bolhuis RLH (1990) ICAMmelanoma cells are relatively resistant to CD3-mediated T-cell lysis. Int J Cancer 46:475

15. Brissinck J, Demanet C, Moser M, Leo O, Thielemans K (1991) Treatment of mice bearing $\mathrm{BCL}_{1}$ lymphoma with bispecific antibodies. J Immunol 147:4019

16. Brissinck J, Demanet C, Moser M, Leo O, Thielemans K (1993) Bispecific antibodies in lymphoma. Int Rev Immunol 10:187

17. Brocker T, Peter A, Traunecker A, Karjalainen K (1993) New simplified molecular design for functional T cell receptor. Eur J Immunol 23:1435

18. Burnett FM (1970) The concept of immunological surveillance. Prog Exp Tumor Res 13:1

19. Campbell IG, Jones TA, Foulkes WD, Trowsdale J (1991) Folate-binding protein is a marker for ovarian cancer. Cancer Res 51:5329

20. Canevari S, Stoter G, Arienti F, Bolis G, Colnaghi MI, Di Re EM, Eggermont AMM, Hoo Goey S, Gratama JW, Lamers CHJ, Nooy MA, Parmiani G, Raspagliesi F, Ravagnani F, Scarfone G, Trimbos JB, Warnaar SO, Bolhuis RLH (1995) Regression of advanced ovarian carcinoma by intraperitoneal 
treatment with autologous $\mathrm{T}$ lymphocytes retargeted by a bispecific monoclonal antibody. J Natl Cancer Inst 87:1463

21. Chothia C, Boswell BW, Lesk AM (1988) The outline structure of T-cell $\alpha \beta$ receptor. EMBO J 7:3745

22. Colcher D, Bird R, Roselli M, Hardman KD, Johnson S, Pope S, Dodd SW, Pantoliano MW, Milenic DE, Schlom J (1990) In vivo tumor targeting of a recombinant single chain antigen-binding protein. J Natl Cancer Inst 82:1191

23. Coulie PG, Uyttenhove C, Wauters P, Manolios N, Klausner RD, Samelson LE, Van Snick J (1991) Identification of a murine monoclonal antibody specific for an allotypic determinant on mouse CD3. Eur J Immunol 21:1703

24. Culty M, Miyake K, Kincade PW, Sikorski E, Butcher EC, Underhill C (1990) The hyaluronate receptor is a member of the CD44 (H-CAM) family of cell surface glycoproteins. J Cell Biol 111:2765

25. Davis MM, Bjorkman PJ (1988) T-cell antigen receptor genes and T-cell recognition. Nature 334:395

26. Demanet C, Brissinck J, Van Mechelen M, Leo O, Thielemans K (1991) Treatment of murine B cell lymphoma with bispecific monoclonal antibodies (anti-idiotype $x$ anti-CD3). J Immunol 147:1091

27. Demanet C, Brissinck J, Moser M, Leo O, Thielemans K (1992) Bispecific antibody therapy of two murine B-cell lymphomas. Int J Cancer 7:67

28. Demanet C, Brissinck J, Leo O, Moser M, Thielemans K (1994) Role of T-cell subsets in the bispecific antibody (anti-idiotype $\mathrm{X}$ anti-CD3) treatment of the $\mathrm{BCL}_{1}$ lymphoma. Cancer Res 54:2973

29. Dennert G, Podack ER (1983) Cytolysis by H-2-specific T killer cells. Assembly of tubular complexes on target membranes. J Exp Med 157:1483

30. Ehrlich P (1909) Ub̈er den jetzigen Stand der Karzinomforschung. Ned Tijdschr Geneeskd 35: 273

31. Eshhar Z, Waks T, Gross G, Schindler DG (1993) Specific activation and targeting of cytotoxic lymphocytes through chimeric single chains consisting of antibody-binding domains and the $\gamma$ or $\zeta$ subunits of the immunoglobulin and T-cell receptors. Proc Natl Acad Sci USA 90:720

32. Eshhar Z, Gross G, Treisman J (1993) Modifying the specificity of T cells using chimeric Ig/TCR genes. In: Gallagher G, Rees RC, Reinolds CW (eds) Practical approach to tumor immunology. IRL Press, Oxford, pp 346-368

33. Eshhar Z, Gross G, Waks T, Lustgarten J, Bach N, Ratner A, Treisman J, Schindler DG (1995) T-bodies: chimeric T-cell receptors with antibody-type specificity. Methods: A companion to Method Enzymol 8:133

34. Galandrini R, Albi N, Tripodi G, Zarcone D, Terenzi A, Moretta A, Grossi CE, Velardi A (1993) Antibodies to CD44 trigger effector functions of human T cell clones. J Immunol 150:4225

35. Garrido MA, Valdayo MJ, Winkler DF, Titus JA, Hecht TT, Perez P, Segal DM, Wunderlich JR (1990) Targeting human $T$ lymphocytes with bispecific antibodies to react against human ovarian carcinoma cells in nu/nu mice. Cancer Res 50:4227

36. Geiger B, Rosen D, Berke G (1982) Spatial relationships of microtubule-organizing centers and the contact area of cytotoxic $T$ lymphocytes and target cells. J Cell Biol 95:137

37. Goedegebuure SP, Segal DM, Braakman E, Vreugdenhil RJ, Krimpen BA van, Van de Griend RJ, Bolhuis RLH (1989) Induction of lysis by TCR $\gamma \delta^{+} / \mathrm{CD} 3^{+} \mathrm{T}$ lymphocytes via $\mathrm{CD} 2$ requires triggering via the T11.1 epitope only. J Immunol 142:1797

38. Goedegebuure SP, Braakman E, Segal DM, Vreugdenhil RJ, Bolhuis RLH (1990) Lymphocyte leukocyte function-associated antigen 1 interacting with target cell intercellular adhesion molecule 1 coactivates cytolysis triggered via CD16 or the receptor involved in major histocompatibility antigenunrestricted lysis. Int Immunol 2:1213

39. Goverman J, Gomez SM, Segesman KD, Hunkapiller T, Lang WE, Hood L (1990) Chimeric immunoglobulin-T-cell receptor complex formation and activation. Cell 60:929

40. Griffiths AD, Williams SC, Hartley O, Tomlinson OM, Waterhouse P, Crosby WL, Kontermann R, Jones PT, Low NM, Allison TJ, Prospero TD, Hoogenboom HR, Nissim A, Cox JPL, Harrison JL, Zaccolo M, Gherardi E, Winter G (1994) Isolation of high affinity human antibodies directly from large synthetic repertoires. EMBO J 13:3245

41. Gross G, Gorochov G, Waks T, Eshhar Z (1989) Generation of effector T cells expressing chimeric $T$ cell receptor with antibody type-specificity. Transplant Proc 21:127

42. Gross G, Waks T, Eshhar Z (1989) Expression of immunoglobulin-T-cell receptor chimeric molecules as functional receptors with antibody-type specificity. Proc Natl Acad Sci USA 86:10024

43. Gross G, Eshhar Z (1992) Endowing T cells with antibody specificity using chimeric $T$ cell receptors. FASEB J 6:3370 
44. Hawkins RE, Llewelyn MB, Russel SJ (1992) Monoclonal antibodies in medicine: adapting antibodies for clinical use. BMJ 305:1348

45. Henkart PA (1994) Lymphocyte-mediated cytotoxicity: two pathways and multiple effector molecules. Immunity $1: 343$

46. Holliger P, Prospero T, Winter G (1993) "Diabodies": small bivalent and bispecific antibody fragments. Proc Natl Acad Sci USA 90:6444

47. Holliger P, Winter G (1993) Engineering bispecific antibodies. Curr Opin Biotechnol 4:446

48. Hoogenboom HR, Griffiths AD, Johnson KS, Chiswell DJ, Hudson P, Winter G (1991) Multi-subunit proteins on the surface of filamentous phage: methodologies for displaying antibody (Fab) heavy and light chains. Nucleic Acids Res 19:4133

49. Hoogenboom HR, Winter G (1992) Bypassing immunisation: human antibodies from synthetic repertoires of germ line VH-gene segments rearranged in vitro. J Mol Biol 20:381

50. Hwu P, Shafer GE, Treisman J, Schindler DG, Gross G, Cowherd R, Rosenberg SA, Eshhar Z (1993) Lysis of ovarian cancer cells by human lymphocytes redirected with a chimeric gene composed of an antibody variable region and the $\mathrm{Fc}$ receptor $\gamma$ chain. $\mathrm{J}$ Exp Med 178:361

51. Ishiura S, Matsuda K, Koizumi H, Tsukahara T, Arahata K, Sugita H (1990) Calcium is essential for both the membrane binding and the lytic activity of pore-forming protein (perforin) from cytotoxic T lymphocytes. Mol Immunol 27:803

52. Itoh N, Yonehara S, Ishii A, Yonehara M, Mizushima S, Sameshima M, Hase A, Seto Y, Nagata $S$ (1991) The polypeptide encoded by the cDNA for human cell surface antigen Fas can mediate apoptosis. Cell 66:233

53. Jain RK (1989) Delivery of novel therapeutic agents in tumors: physiological barriers and strategies. J Natl Cancer Inst 81:570

54. Janssen RAJ, Kroesen BJ, Buter J, Mesander G, Sleijfer DT, The TH, Mulder NH, Ley L de (1995) Immunomodulatory effects of intravenous BIS-1 $\mathrm{F}\left(\mathrm{ab}^{\prime}\right)_{2}$ administration in renal cell cancer patients. Br J Cancer 72:795

55. Jenkins MK (1994) The ups and downs of T cell costimulation. Immunity 1:443

56. Kagi D, Vignaux F, Ledermann B, Burki K, Depraetere V, Nagata S, Hengartner H, Golstein P (1994) Fas and perforin pathways as major mechanisms of $T$ cell-mediated cytotoxicity. Science 265:528

57. Kojima H, Shinohara N, Suda T, Hanaoka S, Someya-Shirota Y, Takaga Y, Ohno H, Saito T, Katayama T, Yagita H, Okumura K, Shinkai Y, Alt FW, Matsuzawa A, Yonehara S, Nagata S, Takayama H (1994) Two distinct pathways of specific killing revealed by perforin mutant cytotoxic T lymphocytes. Immunity 1:357

58. Kostelny SA, Cole MS, Tso (1992) Formation of a bispecific antibody by the use of leucine zippers. J Immunol 148:1547

59. Kroesen BJ, Haar A ter, Spakman H, Willemse P, Seijfer DT, Vries EGE de, Mulder NH, Berendsen HH, Limburg PC, The TH, Leij L de (1993) Local antitumor treatment in carcinoma patients with bispecific-monoclonal-antibody-redirected T cells. Cancer Immunol Immunother 37:400

60. Kroesen BJ, Buter J, Sleijfer DT, Janssen RAJ, Graaf WTA van der, The TH, Leij L de, Mulder NH (1994) Phase I study of intravenously applied bispecific antibody in renal cell cancer patients receiving subcutaneous interleukin 2 . Br J Cancer 70:652

61. Kupfer A, Dennert G, Singer SJ (1985) The reorientation of the Golgi apparatus and the microtubuleorganizing center in the cytotoxic effector cell is a prerequisite in the lysis of bound target cells. $J$ Mol Cell Immunol 2:37

62. Kupfer A, Singer SJ, Janeway CA, Swain SL (1987) Coclustering of CD4 (L3T4) molecule with the $\mathrm{T}$-cell receptor is induced by specific direct interaction of helper $\mathrm{T}$ cells and antigen-presenting cells. Proc Natl Acad Sci USA 84:5888

63. Kuwana Y, Asakura Y, Utsuomiya N, Nakanishi M, Arata Y, Itoh S, Nagase F, Kurosawa Y (1987) Expression of chimeric receptor composed of immunoglobulin-derived $\mathrm{V}$ regions and $\mathrm{T}$-cell receptorderived C regions. Biochem Biophys Res Commun 149:960

64. Lamers CHJ, Gratama JW, Warnaar SO, Stoter G, Bolhuis RLH (1995) Inhibition of bispecific monoclonal antibody (bsAb)-targeted cytolysis by human anti-mouse antibodies in ovarian carcinoma patients treated with bsAb-targeted activated lymphocytes. Int $\mathrm{J}$ Cancer $60: 450$

65. Lanzavecchia A, Scheidegger D (1987) The use of hybrid hybridoma to target human cytotoxic T lymphocytes. Eur J Immunol 17:105

66. Leo O, Foo M, Sachs DH, Samelson LE, Bluestone JA (1987) Identification of a monoclonal antibody specific for a murine T3 polypeptide. Proc Natl Acad Sci USA 84:1374 
67. Lesley J, Hyman R, Kincade PW (1993) CD44 and its interaction with extracellular matrix. Adv Immunol 54:271

68. Lichtenheld MG, Olsen KJ, Lu P, Lowrey DM, Hameed A, Hengartner H, Podack ER (1988) Structure and function of human perforin. Nature 335:448

69. Linsley PS, Ledbetter JA (1993) The role of the CD28 receptor during T cell responses to antigen. Annu Rev Immunol 11:191

70. Lowin B, Hahne M, Mattmann C, Tschopp J (1994) Cytolytic T-cell cytotoxicity is mediated through perforin and Fas lytic pathways. Nature 370:650

71. Lustgarten J, Eshhar Z (1995) Specific elimination of IgE production using $T$ cell lines expressing chimeric $T$ cell receptor genes. Eur J Immunol 25:2985

72. Lynch DH, Watson ML, Alderson MR, Baum PR, Miller RE, Tough T, Gibson M, Davis Smith T, Smith CA, Hunter K (1994) The mouse Fas-ligand gene is mutated in gld mice and is part of a TNF family gene cluster. Immunity $1: 131$

73. Marks JD, Hoogenboom HR, Bonnert TP, McCafferty J, Griffiths AD, Winter G (1991) By-passing immunization: human antibodies from V-gene libraries displayed on phage. J Mol Biol 222:581

74. McCafferty J, Griffiths AD, Winter G, Chiswell DJ (1990) Phage antibodies: filamentous phage displaying antibody variable domains. Nature 348:552

75. Mezzanzanica D, Garrido MA, Neblock DS, Daddona PE, Andrew SM, Zurawski VR Jr, Segal DM, Wunderlich JR (1991) Human T-lymphocytes targeted against an established ovarian carcinoma with bispecific $\mathrm{F}\left(\mathrm{ab}^{\prime}\right) 2$ antibody prolong host survival in a murine xenograft model. Cancer Res 51:5716

76. Moretta A, Poggi A, Pende D, Tripodi G, Orengo AM, Pella N, Augugliaro R, Bottino C, Ciccone E, Moretta L (1991) CD69-mediated pathway of lymphocyte activation: anti-CD69 monoclonal antibodies trigger the cytolytic activity of different lymphoid effector cells with the exception of cytolytic $\mathrm{T}$ lymphocytes expressing $\mathrm{T}$ cell receptor $\alpha / \beta$. J Exp Med 174:1393

77. Moritz D, Wels W, Mattern J, Groner B (1994) Cytotoxic T lymphocytes with grafted recognition specificity for ERBB2-expressing tumor cells. Proc Natl Acad Sci USA 91:4318

78. Nishioka WK, Welsh RM (1994) Susceptibility to cytotoxic T-lymphocyte-induced apoptosis of the proliferative status of the target. J Exp Med 179:769

79. Pack P, Pluckthun A (1992) Miniantibodies: use of amphipathic helices to produce functional, flexibly linked dimeric FV fragments with high avidity in Escherichia coli. Biochemistry 31:1579

80. Perez P, Hoffmann RW, Shaw S, Bluestone JA, Segal DM (1985) Specific targeting of cytotoxic T cells by anti-T3 linked to anti-target cell antibody. Nature $316: 354$

81. Philips JH, Gumperz JE, Parham P, Lanier LL (1995) Superantigen-dependent, cell-mediated cytotoxicity inhibited by MHC class I receptors on T lymphocytes. Science 268:403

82. Podack ER, Hengartner H, Lichtenheld MG (1991) A central role of perforin in lymphocyte-mediated cytotoxicity. Annu Rev Immunol 9:129

83. Qian J-H, Titus JA, Andrew SM, Mezzanzanica D, Garrido MA, Wunderlich JR, Segal DM (1991) Human PBL targeted with bispecific antibodies release cytokines that are essential for inhibiting tumor growth. J Immunol 146:3250

84. Ridge JP, Fuchs EJ, Matzinger P (1996) Neonatal tolerance revisited: turning on newborn T cells with dendritic cells. Science 271:1723

85. Roberts MR, Qin L, Zhang D, Smith DH, Tran A-C, Dull TJ, Groopman JE, Capon DJ, Byrn RA, Finer MH (1994) Targeting of human immunodeficiency virus-infected cells by CD8+ T lymphocytes armed with universal T-cell receptors. Blood 84:2878

86. Romani L, Mocci S, Bietta C, Lanfaloni L, Puccetti P, Bistoni F (1991) Th1 and Th2 cytokine secretion patterns in murine candidiasis: association of Th1 responses with acquired resistance. Infect Immun 59:4647

87. Rosenberg SA, Packard BS, Aebersold PM, Solomon D, Topalian SL, Toy ST, Simon P, Lotze MT, Yang JC, Seipp CA, Simpson C, Carter C, Bock S, Schwartzentruber D, Wei JP, White DE (1988) Use of tumor infiltrating lymphocytes and interleukin- 2 in the immunotherapy of patients with metastatic melanoma. N Engl J Med 319:1676

88. Rosenberg SA, Yanelli JR, Yang JC, Topalian SL, Schwartzentruber DJ, Weber JS, Parkinson DR, Seipp CA, Einhorn JH, White DE (1994) Treatment of patients with metastatic melanoma with autologous tumor-infiltrating lymphocytes and interleukin 2. J Natl Cancer Inst 86:1159

89. Russell JH (1983) Internal disintegration model of cytotoxic lymphocyte-induced target damage. Immunol Rev 72:97 
90. Saizawa K, Rojo J, Janeway JA Jr (1987) Evidence for a physical association of CD4 and the CD3: $\alpha: \beta$ T-cell receptor. Nature 328:260

91. Salmeron A, Sanchez-Madrid F, Ursa MA, Fresno M, Alarcon B (1991) A conformational epitope expressed upon association of $\mathrm{CD} 3$-epsilon with either CD3-delta or CD3-gamma is the main target for recognition by anti-CD3 monoclonal antibodies. J Immunol 147:3047

92. Schwartz RH (1992) Costimulation of T lymphocytes: the role of CD28, CTLA-4, and B7/BB1 in interleukin-2 production and immunotherapy. Cell 71:1065

93. Sconocchia G, Titus JA, Segal DM (1994) CD44 is a cytotoxic triggering molecule in human peripheral blood NK cells. J Immunol 153:5473

94. Segal DM, Snider DP (1989) Targeting and activation of cytotoxic T lymphocytes. Chem Immunol $47: 179$

95. Segal DM, Urch CE, George AJT, Jost CR (1992) Bispecific antibodies in cancer treatment. In: DeVita VT, Hellman S, Rosenberg SA (eds) Biologic therapy of cancer updates, vol.2. Lippincott, Philadelphia, pp 1-12

96. Segal DM, Jost CR, George AJT (1993) Targeted cellular cytotoxicity. In: Sitkovsky MV, Henkart PA (eds) Cytotoxic cells: generation, recognition, effector functions, methods. Springer, New York, Berlin Heidelberg pp 96-110

97. Seth A, Gote L, Nagarkatti M, Nagarkatti PS (1991) T-cell-receptor-independent activation of cytolytic activity of cytotoxic T lymphocytes mediated through CD44 and gp90 $0^{\mathrm{MEL}-14}$. Proc Natl Acad Sci USA 88:7877

98. Shalaby MR, Shepard HM, Presta L, Rodrigues ML, Beverley ACL, Feldmann M, Carter P (1992) Development of humanized bispecific antibodies reactive with cytotoxic lymphocytes and tumor cells overexpressing the HER2 protooncogene. J Exp Med 175:217

99. Shinkai Y, Takio K, Okumura K (1988) Homology of perforin to the ninth component of complement (C9). Nature 334:525

100. Shiver JW, Henkart PA (1991) A noncytotoxic mast cell tumor line exhibits potent IgE-dependent cytotoxicity after transfection with the cytolysin/perforin gene. Cell 64:1175

101. Shiver JW, Su L, Henkart PA (1992) Cytotoxicity with target DNA breakdown by rat basophilic leukemia cells expressing both cytolysin and granzyme A. Cell 71:315

102. Springer TA (1990) Adhesion receptors of the immune system. Nature 346:425

103. Stancovski I, Schindler DG, Waks T, Yarden Y, Sela M, Eshhar Z (1993) Targeting of T lymphocytes to Neu/HER2-expressing cells using chimeric single chain Fv receptors. J Immunol 151:6577

104. Street NE, Mosmann TR (1991) Functional diversity of $T$ lymphocytes due to secretion of different cytokine patterns. FASEB J 5:171

105. Tibben JG, Boerman OC, Claessens RAMJ, Corstens FHM, Van Deuren M, De Mulder PHM, Van der Meer JWM, Keijser KGG, Massuger LFAG (1993) Cytokine release in an ovarian cancer patient following intravenous administration of bispecfic antibody OC/TR F(ab')2. J Natl Cancer Inst 85:1003

106. Titus JA, Garrido MA, Hecht TT, Winkler DF, Wunderlich JR, Segal DM (1987) Human T cells targeted with anti-T3 crosslinked to anti-tumor antibody prevent tumor growth in nude mice. J Immunol $138: 4018$

107. Trauth BC, Klas C, Peters AM, Matzku S, Möller P, Falk W, Debaten K-M, Krammer PH (1989) Monoclonal antibody-mediated tumor regression by induction of apoptosis. Science 245:301

108. Tschopp J, Nabholz M (1990) Perforin-mediated target cell lysis by cytol;tic T lymphocytes. Annu Rev Immunol 8:279

109. Valitutti S, Müller S, Cella M, Padovan E, Lanzavecchia A (1995) Serial triggering of many T-cell receptors by a few peptide-MHC complexes. Nature 375:148

110. Van de Griend RJ, Tax WJM, Van Krimpen BA, Vreugdenhil RJ, Bolhuis RLH (198' 7 ) Lysis of tumor cells by $\mathrm{CD}^{+} 4^{-} 8^{-} 16^{+} \mathrm{T}$ cell receptor $\alpha \beta$ - clones, regulated via $\mathrm{CD} 3$ and $\mathrm{CD} 16$ activation sites, recombinant interleukin 2 and interferon $\beta$. J Immunol 138:1627

111. Van de Griend RJ, Bolhuis RLH, Stoter G, Roozemond RC (1987) Regulation of cytolytic activity in $\mathrm{CD}^{-}$and $\mathrm{CD}^{+}$killer cell cones by monoclonal antibodies (anti-CD16, anti-CD2, anti-CD3) depends on subclass specificity of target cell IgG-FcR. J Immunol 138:3137

112. Van Ravenswaay Claasen HH, Van de Griend RJ, Mezzanzanica D, Bolhuis RLH, Warnaar SO, Fleuren GJ (1993) Analysis of production, purification, and cytolytic potential of bispecific antibodies reactive with ovarian-carcinoma-associated antigens and the $\mathrm{T}$ cell antigen $\mathrm{CD} 3$. Int $\mathrm{J}$ Cancer 55:128 
113. Van Ravenswaay Claasen HH, Eggermont AM, Nooyen YA, Warnaar SO, Fleuren GJ (1994) Immunotherapy in a human ovarian cancer xenograft model with two bispecific monoclonal antibodies: OV-TL3/CD3 and OC/TR. Gynecol Oncol 52:199

114. Van Seventer GA, Shimizu Y, Shaw S (1991) Roles of multiple accessory molecules in T-cell activation. Curr Opin Immunol 3:294

115. Vaughan TJ, Williams AJ, Pritchard K, Osbourn JK, Pope AR, Earnshaw JC, McCafferty J, Hodits RA, Wilton J, Johnson KS (1996) Human antibodies with sub-nanomolar affinities isolated from a large non-immunized phage display library. Nature Biotechnol 14:309

116. Walsh CM, Glass AA, Chiu V, Clark WR (1994) The role of the Fas lytic pathway in a perforin-less CTL hybridoma. J Immunol 153:2506

117. Weiner GJ, Hilstrom JR (1991) Bispecific anti-idiotype/anti-CD3 antibody therapy of murine B cell lymphoma. J Immunol 147:4035

118. Weiner GJ (1992) Bispecific IgG and IL-2 therapy of a syngeneic B-cell lymphoma in immunocompetent mice. Int J Cancer [Suppl] 7:63

119. Weiner GJ, Kostelny SA, Hillstrom JR, Cole MS, Link BK, Wang SL, Tso JY (1994) The role of T cell activation in anti-CD3 $x$ antitumor bispecific antibody therapy. J Immunol 152:2385

120. Wels W, Harwerth IM, Hynes NE, Groner B (1992) Diminution of antibodies directed against tumor cell surface epitopes: a single chain $\mathrm{Fv}$ fusion molecule specifically recognizes the extracellular domain of the c-erb B2 receptor. J Steroid Biochem Mol Biol 43:1

121. Winter G, Milstein C (1991) Man-made antibodies. Nature 349:293

122. Winter G, Griffiths AD, Hawkins RE, Hoogenboom HR (1994) Making antibodies by phage display technology. Annu Rev Immunol 12:433

123. Zhu Z, Zapata G, Shalaby R, Snedecor B, Chen H, Carter P (1996) High level secretion of a humanized bispecific diabody from Escherichia coli. Biotechnology 14:192 